DOI https://doi.org/10.30525/978-9934-26-074-2-5

\title{
ФОРМУВАННЯ ЄВРОПЕЙСЬКОГО ОСВІТНЬОГО ПРОСТОРУ ТА ІНТЕГРАЦІЯ ДО НЬОГО УКРАЇНИ (В ОЦІНКАХ УКРАЇНСЬКИХ НАУКОВЦІВ)
}

\author{
Моісесва Т. М. \\ кандидат історичних наук, \\ дочент кафедри міжнародних відносин та права \\ Державного університету «Одеська політехніка» \\ Воробйова Г. В. \\ кандидат історичних наук, \\ дочент кафедри міжнародних відносин та права \\ Державного університету "Одеська політехніка» \\ Латишева В. В. \\ кандидат наук з державного управління, \\ дочент кафедри міжнародних відносин та права \\ Державного університету «Одеська політехніка» \\ м. Одеса, Україна
}

Свроінтеграційні устремління України диктують необхідність проведення глибоких та якісних реформ в багатьох сферах суспільного життя, в тому числі - освітянській. Важливою умовою та, одночасно, складовою іiі модернізації $\epsilon$ інтеграція до європейського освітнього простору (СОП). Окреслена проблема досить активно досліджується вітчизняними науковцями. Розглянемо декілька ії аспектів.

Iсторична площина формування та еволюції СОП докладно висвітлена в статті Клименко О.В. Відлік цього шляху науковець пов'язує 3 підписанням Свропейської культурної конвенції (1954р.) та Римської угоди (1957 р.). Ідеї, закладені в цих документах, на думку автора, були продовжені у Великій Хартії університетів (підписана в Болоньї, 18 вересня 1988 р., ректорами найстаріших університетів Свропи), якою визначалася мета перетворення європейського континенту на широкий, прозорий і привабливий простір, доступний для вільного пересування студентів, викладачів, дослідників.

Старт новому етапу формування Європейського освітнього простору дав Маастрихтський договір 1992 р., який поклав початок існуванню Свропейського Союзу. 3 цього часу, на різних «майданчиках» (зустрічі 
профільних міністрів, конференції, саміти), ведеться плідна, динамічна робота в напрямку розширення та удосконалення СОП, вироблення спільних підходів до вирішення транснаціональних проблем вищої освіти.

Напрацьовані на міжнародних форумах рішення, знаходили своє втілення у прийнятих документах, серед яких можна назвати: Лісабонську конвенцію (1997 р.); Сорбонську (1998 р.) та Болонську (1999 р.) декларації; Празьке (2001 р.), Берлінське (2003 р.), Бергенське, (2005 р.) Лондонське (2007 р.), Льовенське (2009 р.) комюніке та ін. У березні 2010 р., за підсумками зустрічі міністрів, було прийнято Будапештсько-Віденську Декларацію та офіційно проголошено створення Європейського простору вищої освіти.

Здійснений автором аналіз згаданих актів, дає можливість виділити найбільш важливі кроки міжнародного співтовариства у становленні СОП, які, більшою мірою, були імплементовані в національні законодавства. Серед таких можна назвати: програми приведення національного законодавства у сфері освіти до норм, напрацьованих країнами Європи; підвищення академічної мобільності студентів та їхньої мобільності на ринку праці; запровадження Болонського процесу європейської інтеграції вищої школи та Європейської системи взаємозаліку навчальних кредитів (European Credit-Transfer System, ECTS); введення уніфікованої форми додатку до дипломів та триступеневої системи освіти (бакалавр - магістр - доктор філософії в галузі) та ін. [2, с. 53-60].

Питання реформування початкової освіти, у контексті європейських орієнтирів, у своєму дослідженні підняла О.Б. Ярова. На основі аналізу тенденцій розвитку початкової освіти в країнах $Є С$, вона виділяє три рівні модернізації цієї сфери в Україні: змістовий, організаційний, управлінський. По кожному 3 цих «блоків», автор виокремлює: позитивні та прийнятні, для нашої держави, аспекти європейського досвіду; проблемні питання вітчизняної системи початкової освіти; рекомендації щодо подальшої розбудови національного шкільництва.

Представляють інтерес, акцентовані дослідницею, «прогалини», на рівні управління шкільною освітою в Україні, які вона пов'язує 3 фінансовими, технічними та кадровими проблемами. Автор конкретизує ïx, наголошуючи на: надмірній концентрації повноважень у $\mathrm{MOH}$; дублюванні функцій $\mathrm{MOH}$ i місцевих органів влади (в умовах недостатньої координації їх діяльності); обмежених організаційних та фінансових ресурсах місцевої влади, необхідних для практичної реалізації освітніх реформ [4, с. 35$]$. 
Не зупиняючись, докладно, на численних рекомендаціях, сформульованих О.Б. Яровою, зауважимо, що, до основних напрямків модернізації початкової освіти, вона відносить: реалізацію особистісно орієнтованого підходу до організації навчання задля гармонійного розвитку особистості молодшого школяра; оновлення змісту початкової освіти на компетентнісних засадах; упровадження інтегрованого навчання у початковій ланці; посилення виховного аспекту в навчальному процесі; підготовку нового вчителя для нової української школи [4, с. 32].

Заслуговують на увагу публікації Гальцової О.Л. та Шитікової С.П., присвячені змістовному наповненню модернізації вищої школи України на шляху інтеграції в європейський освітній простір. Авторки зауважують, що головні пріоритети розвитку вищої школи України визначено Законом «Про вищу освіту» [1, с. 23; 3, с. 55]. Водночас, Гальцова О.Л. підкреслює, що метою «модернізації вищої освіти в Україні є створення такої моделі освітнього процесу, в якій би оптимально поєдналися найкращі вітчизняні й зарубіжні традиції» [1, с. 22].

Важливим інструментом реформування вищої освіти України, є їі участь (за підтримки Свропейського Союзу) у конкурсах проектів мобільності і розвитку потенціалу вищих навчальних закладів, в рамках освітніх і дослідницьких програм («Темпус», «Еразмус «Мундус», «Еразмус+», «Жан Моне», «Рамкова програма» і «Горизонт 2020») $[1$, c. $23 ; 3$, с. 54].

Як зазначає Гальцова О.Л., програма «Еразмус+» $\epsilon$ результатом інтеграції європейських програм, що були реалізовані в період 2007-2013 рр.: «Навчання впродовж життя», «Молодь у дії», «Еразмус Мундус», «Tempus», «Alfa», «Edulink», програми співпраці з промислово розвиненими країнами у сфері вищої освіти та ін. [1, с. 23].

Освітня програма «Еразмус+» (програма ЄC у сфері освіти, професійної підготовки, молоді та спорту на період 2014-2020рр.) i дослідницька програма - «Горизонт 2020» (сприяння виконанню науково-дослідних та інноваційних робіт, підвищення їх ефективності) реалізуються відповідними Генеральними директоратами Свропейської Комісії за підтримки Представництва Свропейського Союзу в Україні $[1$, с. $23 ; 3$, с. 58].

Грунтовний аналіз названих конкурсів і програм представлений в статті Шитікової С.П. Автор зазначає, що потенційними заявниками і партнерами освітньої програми «Еразмус+» виступають вищі навчальні заклади всіх країн учасниць програми (33 країни-члени Програми i близько 150 країн-партнерів) [3, с. 56]. Практичну складову освітніх програм та врахування потреб ринку праці, забезпечує долучення до 
партнерства науково-дослідницьких інституцій, підприємств та компаній, неурядових та громадських організацій, органів державної влади та місцевого самоврядування [3, с. 57-58].

Дослідниця підкреслює, що Україна активно долучилася до участі та реалізації науково-освітніх програм ЄС i, для більш ефективного їх запровадження, було здійснено наступні заходи: сформовано відповідні структури - «Національний Еразмус+ офіс в Україні - проект СС», що підтримує двомовний веб-сайт з матеріалами за програмою «Еразмус+»; створено мережу контактних пунктів програми «Горизонт 2020» по всій Україні; розроблено новий портал «Горизонт 2020 Україна», де представлено всі конкурсні документи та переклади українською мовою для зручності зацікавлених сторін. Важливу роль у реформуванні вищої освіти, на думку автора, відіграють члени Національної команди експертів з реформування вищої освіти, в рамках діяльності проекту «Національний Еразмус+ офіс в Україні» [3, с. 59-60].

Особливу увагу дослідниця приділяє визначенню ключових пріоритетів модернізації вищої освіти, серед яких: розроблення стандартів вищої освіти відповідно до нового переліку галузей знань і спеціальностей на основі компетентнісного підходу; розроблення галузевих рамок кваліфікацій із залученням роботодавців; розвиток процедур і механізмів запровадження інструментів інтернаціоналізації вищої освіти і запровадження проектів міжнародної технічної допомоги та ін. [3, с. 61].

\section{Література:}

1. Гальцова О. Л. Міжнародна співпраця України 3 країнами Європи в галузі освіти. Причорноморські економічні студіï. 2019. Вип. 44. С. 21-26.

2. Клименко О.В. Формування та розвиток Європейського освітнього простору. Бібліотекознавство. Документознавство. Інформологія. 2012. № 1. С. 53-60.

3. Шитікова С. П. Програми Європейського Союзу для реформування вищої освіти. Освітологічний дискурс. 2016. № 2. С. 53-64.

4. Ярова О. Б. Досвід розвитку початкової освіти в країнах ЄС - джерело модернізації початкової освіти в Україні. Украӥнський педагогічний журнал. 2018. № 1. С. 31-37. 